Stałą częścią każdego seminarium są wycieczki studialne przygotowywane i prowadzone, głównie przez pracowników naukowych Instytutu Geografii Miast i Turyzmu, po regionie, w którym odbywa się seminarium.

W seminariach terenowych „Warsztaty badawcze z geografii turyzmu" każdego roku uczestniczy po kilkadziesiąt osób (30-50), nie tylko geografów, co umożliwia stały przeplyw aktualnej wiedzy badawczej realizowanej $\mathrm{w}$ różnych ośrodkach naukowych zajmujących się turystyką zarówno w Polsce, jak i w innych krajach.

Ostatnie, XXIII seminarium zgrupowało badaczy z siedmiu polskich uniwersytetów (Lódź, Kraków, Lublin, Poznań, Szczecin, Gdańsk, Bydgoszcz), a także z Akademii Ekonomicznych (Wrocław, Poznań), Akademii Rolniczej w Poznaniu i Akademii Pomorskiej w Shupsku. W seminarium uczestniczyli również pracownicy naukowi z prywatnych wyższych szkół w Białymstoku, Lodzi i Rzeszowie. Tak więc w pracach seminarium brali udział przedstawiciele 10 największych miast $w$ Polsce. Sporadycznie w tych cyklicznych spotkaniach biorą udział naukowcy z ośrodków akademickich w Pradze, Bratysławie i miast Rosji.

Wszystkie seminaria terenowe są szczegółowo dokumentowane, a ich przebieg i tematyka publikowane są w dziale „Sprawozdania” czasopisma Turyzm.

Elżbieta Dziegieć

\section{Międzynarodowe konferencje naukowe pt. „Uwarunkowania rozwoju turystyki zagranicznej w Europie Środkowej i Wschodniej" organizowane przez Zakład Geografii Regionalnej i Turystyki Uniwersytetu Wroclawskiego}

Od roku 1990, co dwa lata, Zakład Geografii Regionalnej i Turystyki Instytutu Geografii i Rozwoju Regionalnego Uniwersytetu Wrocławskiego organizuje międzynarodowe konferencje naukowe pt. „Uwarunkowania rozwoju turystyki zagranicznej w Europie Środkowej i Wschodniej". Zamysłem organizatorów było stworzenie możliwości wymiany doświadczeń badawczych ekspertów turystycznych z postsocjalistycznych krajów europejskich w zakresie rozwoju turystyki zagranicznej w nowych warunkach gospodarki rynkowej. Obserwacje te są konfrontowane
A part of each seminar is an excursion in the area where the seminar is held, prepared and usually led by the academics working at the Institute of Urban Geography and Tourism.

The workshops are attended by $30-50$ participants every year, and not only geographers, allowing an exchange of experience from different academic centres both in Poland and other countries.

The latest, the $18^{\text {th }}$ seminar, hosted researchers from seven Polish universities (Łodź, Kraków, Lublin, Poznañ, Szczecin, Gdańsk, Bydgoszcz), as well as from Academies of Economics in Wrocław and Poznan, the Agricultural Academy in Poznan and the Pomeranian Academy in Slupsk. Other participants came from private higher education institutions in Białystok, Łódż and Rzeszów and in fact, the seminar was attended by representatives of the 10 largest cities in Poland. Occasionally there have been participants from Prague, Bratislava and several Russian cities.

All field seminars are documented in detail and the issues discussed are published in the 'Reports' section of Turyzm.

Elżbieta Dziegieć
Every second year since 1990 the Department of Regional Geography and Tourism has organized international academic conferences entitled 'Conditions for Foreign Tourism Development in Central and Eastern Europe'. The idea behind the conferences was to create an opportunity for experts on tourism from post-communist European countries to exchange their research experiences on foreign tourism in the new world of a market economy. These observations are confronted with the experiences of other European 
$\mathrm{z}$ doświadczeniami innych krajów europejskich o bogatej rynkowej tradycji turystycznej.

Do tej pory zorganizowano dziewięć konferencjiw 1990 r. w Borowicach, w 1992 w Międzygórzu, w 1994 r. w Miłkowie k. Karpacza, w 1996 w Szklarskiej Porębie, w 1998 r. w Sobótce-Górce, w 2000 w Kudowie Zdroju, w 2002 r. w Zamku Czocha, w 2004 we Wrocławiu i w 2006 r. w Polanicy Zdroju. Objazdy terenowe związane $\mathrm{z}$ konferencjami pozwoliły zaprezentować uczestnikom konferencji najciekawsze obszary, miejscowości i obiekty Dolnego Śląska przyczyniając się do promocji turystycznej regionu. Kierownikiem naukowym konferencji był prof. dr hab. Jerzy Wyrzykowski, kierownik Zakładu Geografii Regionalnej i Turystyki. W roku 2008 zorganizowana zostanie dziesiąta, jubileuszowa konferencja, której tematem będzie „Turystyka w środowisku geograficznym".

Uczestnikami i autorami referatów konferencyjnych byli przedstawiciele zagranicznych uniwersytetów i ośrodków badawczych z: Brna, Bratysławy, Dortmundu, Forssy (Finlandia), Kecskemet (Węgry), Lille, Lyonu, Lwowa, Mińska, Monachium, Moskwy, Oradei (Rumunia), Poitiers, Pulman (USA), SighetuMarmatiei (Rumunia), Sofii, Strasburga, Wiednia, Wilna, Zadaru, Zagrzebia oraz polskich uczelni wyższych i ośrodków badawczych z: Bydgoszczy, Gdańska, Katowic, Kłodzka, Krakowa, Łodzi, Opola, Poznania, Szczecina, Wałbrzycha, Warszawy i Wrocławia.

Opierając się na opracowaniach prezentowanych na konferencjach wydano dziewięć zeszytów naukowych w wersji angielskiej i siedem zeszytów w wersji polskiej (nie wydano wersji polskiej zeszytu pierwszego i ósmego). Tematyka zeszytów jest odzwierciedleniem programów konferencyjnych.

W zeszycie pierwszym (wydanym w 1992 r.) znalazły się omówienia: geograficznych aspektów rozwoju turystyki zagranicznej w dawnym Związu Radzieckim, z porównaniami odnoszącymi się do innych krajów bloku socjalistycznego (I. Pirożnik), uwarunkowań geograficznych rozwoju turystyki zagranicznej w dawnej Czechosłowacji (P. Mariot, E. Otrubova, J. Vystoupil), w dawnej Jugosławii (Z. Pepeonik), w Polsce (B. Mikułowski, J. Wyrzykowski), w tym w Sudetach (J. Czerwiński), w Bułgarii, traktowanej jako kraj w kryzysie (M. Bachvarov), a także przestrzeni turystycznej Europy Wschodniej w świetle francuskich katalogów turystycznych (J.-M. Dewailly).

Zeszyt drugi (1993) obejmuje próby oceny: atrakcyjności turystycznej krajobrazów Europy Środkowej i Wschodniej (L. Baraniecki), obszarów, miejscowości i obiektów turystycznych Białorusi (I. Pirożnik), Słowacji (P. Mariot) i Polski (B. Mikułowski, E. Pie- countries with rich market economy tourist traditions.

So far nine conferences have been organised: Borowice (1990), Międzygórze (1992), Miłkôw near Karpacz (1994), Szklarska Poręba (1996), Sobótka-Górka (1998), Kudowa Zdrôj (2000), Czocha Castle (2002), Wrocław (2004) and Polanica Zdrój (2006). Field tours have allowed the participants to see the most interesting areas, towns and buildings of Lower Silesia contributing to the tourist promotion of the region. The academic director of all the conferences has been Prof. Jerzy Wyrzykowski, the head of the Department of Regional Geography and Tourism and the $10^{\text {th }}$ (jubilee) conference will be organized in 2008 when the topic will be Tourism in the Geographical Environment'.

Participants and speakers have represented universities and research centres from Brno, Bratislava, Dortmund, Forssa - Finland, Kecskemet - Hungary Lille, Lyon, Lvov, Minsk, Munich, Moscow, Oradea, Poitiers, Pullman - USA Sighetu-Marmatiea - Romania, Sofia, Strasbourg, Vienna, Vilnius, Zadar, Zagreb. From Polish universities and research centres in Bydgoszcz, Gdanisk Katowice, Kłodz ko, Kraków, Łódź, Opole, Poznań, Watbrzych, Warsaw and Wrocław.

On the basis of studies presented at the conferences nine Notes have been published (Zeszyty Naukowe) in an English language version and seven in a Polish version (there was no Polish version for Notes one and eight). Their topics reflect the conference programmes.

The first Notes (published in 1992) contained the following reports: geographical aspects of foreign tourism development in the former Soviet Union with comparisons referring to other post-communist countries (Pirożnik), the geographical conditioning of foreign tourism development in the former Czechoslovakia (Mariot, Otrubova \& Vystoupil), in the former Yugoslavia (Pepeonik), in Poland (Mikułowski \& Wyrzykowski), in the Sudety mountains (Czerwiński), in Bulgaria, accounted for as a country under crisis (Bachvarov), and also tourism space of Eastern Europe in the light of French tourist catalogues (Dewailly).

Notes number two (1993) covers some attempts to evaluate: the tourist attractiveness of Central and Eastern Europe's landscape (Baraniecki), areas, towns and tourist attractions in Belarus (Pirożnik), Slovakia (Mariot) and Poland (Mikułowski, Pietra- 
traszewska, J. Wyrzykowski), stanu i perspektyw rozwoju turystyki zagranicznej w Chorwacji (V. Mikačic, Z. Pepeonik), perspektyw rozwoju turystyki w europejskiej części Rosji (J.S. Putrik), stanu i perspektyw niemieckiej turystyki przyjazdowej do Polski (R. Paesler), a także analizę porównawczą kosztów podróży do Europy Środkowej i Wschodniej z kosztami innych podróży, w świetle ofert francuskich biur podróży (C. Sobry).

W zeszycie trzecim (1995) przedstawiono m.in. oceny uwarunkowań rozwoju turystyki zagranicznej w Albanii (W. Fedyk), możliwości rozwoju turystyki uzdrowiskowej oraz perpektywiczne ośrodki i trasy turystyki zagranicznej na Białorusi (I. Pirożnik, G. Potajew, H. Potajewa), zmiany strukturalne w turystyce zagranicznej na Słowacji (P. Mariot), wplyw wojny na turystykę zagraniczną w Chorwacji i Bośni-Hercegowinie (V. Mikačic, Z. Hendija, P. Jordan), próbę wskazania modelu turystyki zagranicznej w Bułgarii (M. Bachvarov), charakterystykę turystyki w Europie Wschodniej (L. Kreck), kierunki rozwoju turystyki niemieckiej oraz ich prawdopodobny wplyw na kraje Europy Środkowej i Wschodniej, analizę porównawczą zagospodarowania turystycznego Bawarii i Dolnego Śląska (H.-D. Haas, J. Łoboda, R. Paesler. J. Wyrzykowski), doświadczenia z francusko-polskiej współpracy w zakresie turystyki (J.-M. Dewailly).

Zeszyt czwarty (1997) zawiera m.in. omówienie perspektyw rozwoju turystyki sentymentalnej w Europie Środkowej i Wschodniej (L. Baraniecki) oraz na Dolnym Śląsku i we Wrocławiu (L. Kreck, J. Wyrzykowski), uwarunkowań rozwoju turystyki uzdrowiskowej w Rumunii (W. Fedyk), walorów turystycznych Białorusi dla turystyki zagranicznej (I. Pirożnik), potencjału turystycznego Karpat Ukraińskich (O. Shabliy, Z. Kuczabska), problemów metodycznych oceny międzynarodowych atrakcji turystycznych w tej części Europy (P. Jordan, R. Paesler), stopnia rozwoju turystyki zagranicznej w Europie Środkowej i Wschodniej (J. Wyrzykowski), turystyki na Węgrzech (L. Csordás), znaczenia wysp w zagranicznej turystyce przyjazdowej w Chorwacji (V. Mikačic, Z. Pepeonik).

Zeszyt piąty (1999) poświęcony został problematyce turystyki alternatywnej. Przedstawiono w nim m.in. pojęcie turystyki alternatywnej (M. Bachvarov), turystykę wiejską na Węgrzech (L. Csordás), w Rumunii (J-M. Dewailly), agroturystykę na Dolnym Śląsku i Śląsku Opolskim (W. Fedyk), turystykę dziedzictwa w Chorwacji (V. Mikačic, V. Kelemen-Pepeonik), na Dolnym Śląsku (J. Kołaczek) i we Wrocławiu (A. Galla), turystykę etniczną na Białorusi (O. Mechkovskaya) i przykłady hiszpań- szewska \& Wyrzykowski), the condition and foreign tourism development prospects in Croatia (Mikačic \& Pepeonik), the prospects of tourism development in the European part of Russia (Putrik), the condition and prospects for German incoming tourism to Poland (Paesler), and also a comparative analysis of the cost of travelling in Central and Eastern Europe with regards to travelling in other regions, in the light of the offer of French tourist agencies (Sobry).

The third Notes (1995) presented, among others, evaluations of conditions for foreign tourism development in Albania (Fedyk), the possibilities of spa tourism development and prospective centres and routes for international tourism in Belarus (Pirożnik, Potajew \& Potajewa), structural changes in foreign tourism in Slovakia (Mariot), the impact of the Balkan war on international tourism in Croatia and Bosnia-Herzegovina (Mikačic, Hendija \& Jordan), an attempt to build a model for foreign tourism in Bulgaria (Bachvarov), a characteristics of tourism in Eastern Europe (Kreck), the directions for German tourism development as well as their probable influence on Central and Eastern Europe, a comparative analysis of tourist development in Bayern and Lower Silesia (Haas, Łoboda, Paesler \& Wyrzykowski), the experience of French-Polish cooperation in the scope of tourism (Dewailly).

Notes number four (1997) brought discussion over prospects for sentimental tourism development in Central and Eastern Europe (Baraniecki, in Lower Silesia and in Wrocław (Kreck \& Wyrzykowski), the conditioning of spa tourism development in Romania (Fedyk), Belarus's attractions for foreign tourists (Pirożnik), tourist potential of the Ukrainian Carpathian Mountains (Shabliy \& Kuczabska), methodological problems of evaluating international tourist attractions in Central and South-Eastern Europe (Jordan \& Paesler), the degree of development of foreign tourism in Central and Eastern Europe (Wyrzykowski), tourism in Hungary (Csordás), the significance of islands for foreign incoming tourist traffic in Croatia (Mikačic \& Pepeonik).

Notes number five (1999) was devoted to alternative tourism. The notion of alternative tourism (Bachvarov), village tourism in Hungary (Csordás), in Romania (Dewailly), agro tourism in Lower Silesia and Opole Silesia (Fedyk), heritage tourism in Croatia (Mikačic \& Kelemen-Pepeonik), in Lower Silesia (Kołaczek) and in Wrocław (Galla), 
skie (K. Widawski), perspektywy turystyki alternatywnej na Białorusi (A. I. Tarasionak), w Niemczech (R. Paesler) oraz na Dolnym Śląsku i Śląsku Opolskim (J. Marak, J. Wyrzykowski).

W zeszycie szóstym (2000-2001) dominują opracowania dotyczace zmian $\mathrm{w}$ turystyce $\mathrm{w}$ ostatnim dziesięcioleciu. Prezentowane są one m.in. na przykładzie turystyki europejskiej (J.-M. Dewailly), Europy Środkowej i Wschodniej (O. Mechkovskaya), turystyki śródziemnomorskiej (V. Mikačic, V. Kelemen-Pepeonik) i wybrzeża Costa Blanca (P. Marchand), Bialorusi (T. Fedortsova), Chorwacji (Z. Pepeonik, Z. Curič), Niemiec Wschodnich (R. Paesler), Polski (K. Klementowski, J. Marak, J. Wyrzykowski, E. Dziegieć, R. Wiluś, Z. Werner, M. Duda), polskiej turystyki zimowej w Austrii (P. Jordan). Ponadto scharakteryzowano atrakcyjność turystyczną wielokulturowego dziedzictwa Europy Środkowo-Wschodniej i jej wykorzystanie (A. Bajcar), tendencje w rozwoju ekoturystyki na Syberii (J. Kononov, M. D. Ananicheva) i nowe koncepcje geograficzne rozwoju turystyki na małych wyspach chorwackich (D. Magač, J. Brkić-Vejmelka, J. Faričić).

Zeszyt siódmy (2002-2003) poświęcony został problemom rozwoju ekoturystyki głównie obszarów górskich. Przedstawione one zostałym m.in. na przykładach obszarów górskich Bułgarii (M. Bachvarov), Czech (J. Ahtola), Rumunii (A. Ilieş, O. Dehoorne, M. Ilieş, I. Josan, R. Petrea, M. Staşac), Bawarii (R. Paesler), Karpat Ukraińskich (J. Zinko), Masywu Wogezów (B. Kostrubiec), polskich Sudetów i Karpat (J. Czerwiński, J. Marak, J. Wyrzykowski, W. Hasiński, K. R. Mazurski, D. Szewczak). Ponadto zaprezentowano metodę szacunkową określania poziomu atrakcyjności krajobrazu dla turystyki (T. Fedortsova) i metody określania pojemności turystycznej obszarów górskich (M. Pstrocka).

Zeszyt ósmy (2004-2005) zawiera opracowania dotyczace stanu obecnego i perspektyw rozwojowych turystyki miejskiej, w ujęciu międzynarodowym i krajowym w Europie Środkowej i Wschodniej (M. Bachvarov, A. Matczak), w Chorwacji (V. Mikačic), Czechach (M. Šauer, J. Vystoupil), Polsce (K. Klementowski, Z. Werner) oraz regionalnym - na Istrii (K. Bučar), na Śląsku (A. Jankowski, A. Nitkiewicz-Jankowska), w Pradze (J. Ahtola), Glogowie (M. Helt), Krakowie (M. Mika, K. Rotter), Lwowie (R. Nowacki), Łodzi (J. Latosińska), Oradei (A. Badulescu, N. Bugnar, D. Badulescu, A. Ilieş, G. Ilieş, O. Dehoorne, C. Tătar), Wrocławiu (J. Wyrzykowski, J. Marak, K. Klementowski, M. Soltysik). Przedstawiono także przykłady różnych rodzajów potencjału turystycznego miast - ethnic tourism in Belarus (O. Mechkovskaya), Spanish examples (Widawski), the prospects of alternative tourism in Belarus (A. I. Tarasionak), in Germany (Paesler) and in Lower and Opole Silesias (Marak \& Wyrzykowski) were all presented.

Notes number six $(2000,2001)$ is dominated by studies describing the changes in tourism over the previous decade. They are presented, among others, on the example of European tourism (J-M. Dewailly), Central and Eastern Europe (Mechkovskaya), Mediterranean tourism (Mikačic \& KelemenPepeonik) and Costa Blanca coast (Marchand), Belarus (Fedortsova), Croatia (Pepeonik, \& Curič), East Germany (Paesler), Poland (Klementowski, Marak, Wyrzykowski, Dziegieć, Wiluś, Werner \& M. Duda), Polish winter tourism in Austria (Jordan). Moreover, the tourist appeal of the multi-cultural heritage of Central and Eastern Europe and its exploitation were characterized (Bajcar), the tendencies in ecotourism in Siberia (Kononov \& Ananicheva) and new geographical concepts for tourism development on small islands in Croatia (Magač, Brkić-Vejmelka \& Faričić).

The seventh Notes $(2002,2003)$ was devoted to the development of ecotourism with the special focus on mountain regions. These were presented on the example of mountainous areas of Bulgaria (Bachvarov), the Czech Republic (Ahtola), Romania (A. Ilieş, Dehoorne, M. Ilieş, Josan. Petrea \&. Staşac), Bayern (Paesler), the Ukrainian Carpathians (Zinko), the Vosges massif (Kostrubiec), the Polish Sudety and Carpathians (Czerwiński, Marak, Wyrzykowski, Hasiński, Mazurski \& Szewczak). Furthermore, an estimation method for determining a landscape's tourist attractiveness level was presented (Fedortsova) together with ways to determine tourist capacity of mountainous regions (Pstrocka).

Notes number eight contains studies concerning the current condition, as well as development prospects, for city tourism international and domestic in Central and Eastern Europe (Bachvarov \&. Matczak), in Croatia (Mikačic), in the Czech Republic (Šauer \& Vystoupil), in Poland (Klementowski \& Werner), as well as regional - on Istria (Bučar), Silesia (Jankowski \& NitkiewiczJankowska), Prague (Ahtola), Głogów (Helt), Kraków (Mika \& Rotter), Lvov Nowacki), Łódź (Latosińska), Oradea (Badulescu, Bugnar, Badulescu, A. Ilieş, G. Ilieş, Dehoorne \& Tătar), Wrocław (Wyrzykowski, Marak, Kle- 
dziedzictwo kulturowe (M. Wyrzykowska), w tym przemysłowe (B. Kostrubiec, M. Lamparska-Wieland, G. Jankowski, A. Staszewska-Ludwiczak), skanseny i imprezy folklorystyczne (G. Galant, K. Widawski), urządzenia i imprezy sportowe (C. Sobry, J. Willms), ocenę usług turystycznych miasta w opinii turystów (D. Milewski, A. Pawlicz), problemy promocji internetowej miast (W. Fedyk, M. Gurak) oraz zasady organizacji przestrzennej ruchu turystycznego w mieście (R. Przybyszewska-Gudelis).

Zeszyt dziewiaty (2006-2007) poświęcony został problematyce turystyki uzdrowiskowej. Przedstawiono w nim środowiskowe uwarunkowania rozwoju turystyki uzdrowiskowej w różnych ujęciach: krajów Europy Środkowej i Wschodniej (O. Mechkovskaya), Białorusi (T. Fedortsova), Litwy (A. Stanaitis), regionu Maramures (A. Ilieş, G. Ilieş), Dolnego Śląska i Sudetów (M. Wyrzykowska, M. Duda-Seifert), polskich Karpat (M. Mika, R. Pawlusiński) oraz miejscowości - Druskienniki (S. Stanaitis, A. Baranauskas), Krynica Zdrój (R. Nowacki), Szczawno Zdrój (J. Wójcie); współczesne modele turystyki uzdrowiskowej - na świecie (A. Hadzik), w Czechach (M. Saper, J. Vystoupil), Francji i Hiszpanii (K. Widawski), Polsce (J. Marak, S. Oparka, J. Wyrzykowski); perspektywy rozwoju turystyki uzdrowiskowej, m.in. na przykładzie Czech (J. Ahtola), Polski (M. Soltysik, R. Gawlik, J. Zajączkowski) i Karpat Ukraińskich (J. Zinko, M. Malska, M. Malski, R. Szczeciński).

Uczestnikami i autorami referatów byli przedstawiciele zagranicznych uniwersytetów i ośrodków badawczych z Brna, Bratysławy, Dortmundu, Forssy (Finlandia), Kecskemet (Węry), Lille, Lyonu, Lwowa, Mińska, Monachium, Moskwy, Oradei (Rumunia), Poitiers, Pulman (USA), Sighetu-Marmatiei (Rumunia), Sofii, Strasburga, Wiednia, Wilna, Zadaru, Zagrzebia oraz polskich uczelni wyższych i ośrodków badawczych z Bydgoszczy, Gdańska, Katowic, Kłodzka, Krakowa, Łodzi, Opola, Poznania, Szczecina, Wałbrzycha, Warszawy i Wrocławia.

$\mathrm{Z}$ przeglądu kilkunastoletniego dorobku konferencji sądzić można, że stanowi on znaczne pogłębienie rozpoznania uwarunkowań rozwoju turystyki zagranicznej w Europie Środkowej i Wschodniej oraz podstawę do kształtowania polityki turystycznej w tym zakresie. mentowski \& Soltysik). Examples were also presented of differing types of tourist potential of cities - cultural heritage (Wyrzykowska), including the industrial (Kostrubiec, Lamparska-Wieland, Jankowski, Staszewska-Ludwiczak), heritage parks and folklore events (Galant \& Widawski), sporting events and facilities (Sobry \& Willms), the evaluation of a city's tourist services in the eyes of visitors (Milewski \& Pawlicz), issues concerning promoting cities in the internet (Fedyk \& Gurak) and theoretical rules for spatial organization of tourism in a city (Przybyszewska-Gudelis).

The ninth Notes $(2006,2007)$ is devoted to issues of spa tourism. It presents environmental conditions for the development of spa tourism in different depictions: for Central and Eastern Europe (Mechkovskaya), for Belarus (Fedortsova), Lithuania (Stanaitis), for the Maramures region (A. Ilieş \& G. Ilieş), for Lower Silesia and the Sudety mountains (Wyrzykowska \& Duda-Seifert), the Polish Carpathians (Mika \& Pawlusiński) and for individual towns - Drukinninkai (Stanaitis \& Baranauskas), Krynica Zdrój (R. Nowacki), Szczawno Zdrój (Wójcie); contemporary models of spa tourism - world-wide (Hadzik), in the Czech Republic (Saper \& Vystoupil), in France and Spain (Widawski), in Poland (Marak, Oparka \& Wyrzykowski); prospects for the development of spa tourism, among others on the example of the Czech Republic (Ahtola), Poland (Sołtysik, Gawlik \& Zajaczkowski) and the Ukrainian Carpathians (Zinko, Malska, Malski \& Szczeciński).

On reviewing well over a decade of conferences it can be justified to state that they have constituted considerable progress in the exploration of the conditions required for the development of international tourism in Central and Eastern Europe. They are also the basis to shape tourist policies in that way. 